\title{
Correction to: Embedding similarities between embryos and circulating tumor cells: fundamentals of abortifacients used for cancer metastasis chemoprevention
}

\author{
Jie Wang ${ }^{1 \dagger}$, Xiaobo Yu ${ }^{2 \dagger}$, Huayi Peng ${ }^{3 \dagger}$, Yusheng Lu' ${ }^{1}$, Shuhui Li ${ }^{2}$, Qing Shi ${ }^{2}$, Jian Liu ${ }^{2}$, Haiyan Dong ${ }^{4}$, \\ Vladimir Katanaev ${ }^{1,5}$ and Lee Jia ${ }^{1 *}$ (1)
}

\section{Correction to: J Exp Clin Cancer Res 40, 300 (2021)}

https://doi.org/10.1186/s13046-021-02104-4

Following publication of the original article [1], an error was found in the Author's contributions section. The correct details should read as:

"Lee Jia designed, wrote and supervised the study. Xiaobo Yu, Jie Wang, Huayi Peng, Qing Shi performed all experiments. Yusheng Lu, Shuhui Li, Jian Liu, Haiyan Dong, and Vladimir Katanaev participated in data analyses, or technology consultations."

Furthermore, author affiliations and their corresponding affiliation details are updated to:

Jie $\mathrm{Wang}^{1+}$, Xiaobo $\mathrm{Yu}^{2+}$, Huayi Peng ${ }^{3+}$, Yusheng $\mathrm{Lu}^{1}$, Shuhui $\mathrm{Li}^{2}$, Qing $\mathrm{Shi}^{2}$, Jian Liu ${ }^{2}$, Haiyan Dong ${ }^{4}$, Vladimir Katanaev $^{1,5}$ and Lee Jia ${ }^{1, "}$

${ }^{1}$ College of Materials and Chemical Engineering, Minjiang University, 350108 Fuzhou, China.

${ }^{2}$ Cancer Metastasis Alert and Prevention Center, College of Chemistry; Fujian Provincial Key Laboratory of Cancer Metastasis Chemoprevention and Chemotherapy, Fuzhou University, 350108 Fuzhou, P.R. China.

The original article can be found online at https://doi.org/10.1186/s13046021-02104-4.

*Correspondence: cmapcjia1234@163.com

† Jie Wang, Xiaobo Yu and Huayi Peng contributed equally to this work

${ }^{1}$ College of Materials and Chemical Engineering, Minjiang University,

Fuzhou 350108, China

Full list of author information is available at the end of the article
${ }^{3}$ Fujian Provincial Key Laboratory of Inspection and Quarantine Technology Research/ Technology Center of Fuzhou Customs, 350108 Fuzhou, China.

${ }^{4}$ Fujian Key Laboratory for Translational Research in Cancer and Neurodegenerative Diseases Institute for Translational Medicine, School of Basic Medical Sciences, Fujian Medical University, 350108 Fuzhou, China.

${ }^{5}$ Translational Research Center in Oncohaematology, Department of Cell Physiology and Metabolism, Faculty of Medicine, University of Geneva, Geneva, Switzerland.

The correction does not have any effect on the results or conclusions of the paper. The original article has been corrected.

\section{Author details}

${ }^{1}$ College of Materials and Chemical Engineering, Minjiang University, Fuzhou 350108, China. ${ }^{2}$ Cancer Metastasis Alert and Prevention Center, College of Chemistry, Fujian Provincial Key Laboratory of Cancer Metastasis Chemoprevention and Chemotherapy, Fuzhou University, 350108 Fuzhou, P.R. China. ${ }^{3}$ Fujian Provincial Key Laboratory of Inspection and Quarantine Technology Research/Technology Center of Fuzhou Customs, Fuzhou 350108 , China. ${ }^{4}$ Fujian Key Laboratory for Translational Research in Cancer and Neurodegenerative Diseases Institute for Translational Medicine, School of Basic Medical Sciences, Fujian Medical University, Fuzhou 350108, China. ${ }^{5}$ Translational Research Center in Oncohaematology, Department of Cell Physiology and Metabolism, Faculty of Medicine, University of Geneva, Geneva, Switzerland.

Published online: 22 October 2021

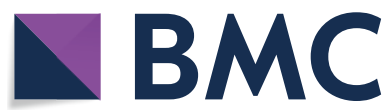

(c) The Author(s) 2021. Open Access This article is licensed under a Creative Commons Attribution 4.0 International License, which permits use, sharing, adaptation, distribution and reproduction in any medium or format, as long as you give appropriate credit to the original author(s) and the source, provide a link to the Creative Commons licence, and indicate if changes were made. The images or other third party material in this article are included in the article's Creative Commons licence, unless indicated otherwise in a credit line to the material. If material is not included in the article's Creative Commons licence and your intended use is not permitted by statutory regulation or exceeds the permitted use, you will need to obtain permission directly from the copyright holder. To view a copy of this licence, visit http://creativecommons.org/licenses/by/4.0/. The Creative Commons Public Domain Dedication waiver (http://creativeco mmons.org/publicdomain/zero/1.0/) applies to the data made available in this article, unless otherwise stated in a credit line to the data. 


\section{Reference}

1. Wang J, Yu X, Peng H, et al. Embedding similarities between embryos and circulating tumor cells: fundamentals of abortifacients used for cancer metastasis chemoprevention. J Exp Clin Cancer Res. 2021;40:300. https:// doi.org/10.1186/s13046-021-02104-4.

- fast, convenient online submission

- thorough peer review by experienced researchers in your field

- rapid publication on acceptance

- support for research data, including large and complex data types

- gold Open Access which fosters wider collaboration and increased citations

- maximum visibility for your research: over $100 \mathrm{M}$ website views per year

At BMC, research is always in progress.

Learn more biomedcentral.com/submissions 